\title{
Effect of different levels of inorganic fertilizer and sulphur on physico-chemical properties of soil, and yield of mustard (Brassica juncea L.)
}

\section{KAILASH CHAND NAGAR, HEMRAJ MEENAAND NARENDRA SWAROOP}

Received : 25.05.2015; Revised : 13.10.2015; Accepted : 27.10.2015

MEMBERS OF RESEARCH FORUM:
Corresponding author :
KAILASH CHAND NAGAR,
Department of Soil Science,
Allahabad School of Agriculture, Sam
Higginbottom Institute of
Agriculture, Technology and
Sciences, ALLAHABAD (U.P.) INDIA
Email: nagarkailash03@gmail.com

Email: nagarkailash03@gmail.com

Co-authors :

HEMRAJ MEENA AND NARENDRA

SWAROOP, Department of Soil

Science, Allahabad School of

Agriculture, Sam Higginbottom

Institute of Agriculture, Technology

and Sciences, ALLAHABAD (U.P.)

INDIA

Email: hemraj3158@gmail.com;

narendraswaroop1958@gmail.com

\section{Summary}

A field experiment was conducted during Rabi season 2012-13 to study the effect of different levels of inorganic fertilizer and sulphur on physico-chemical properties of soil and yield of mustard (Brassica juncea L.). The area is situated on the right bank adjacent to Yamuna river in south of Allahabad city, which is located at $25^{\circ} 27^{\prime} \mathrm{N}$ Latitude and $81^{\circ} 51^{\prime} \mathrm{E}$ Longitude and 98 meter above the mean sea level having the mean temperature during the growing period was 4.7 to $37.2{ }^{\circ} \mathrm{C}$. The soil texture class sandy loam, experimental area falls in order of inceptisol. The design applied for statistical analysis $3^{2}$ Factorial Randomized Block Design having three factors with three levels of NPK 0,50 , and 100 per cent ha ${ }^{-1}$, three levels of sulphur 0,50 , and 100 per cent ha ${ }^{-1}$, respectively were replicated thrice. The best treatment was $\mathrm{T}_{8}-\mathrm{L}_{2} \mathrm{~S}_{2}\left[@ 100 \% \mathrm{NPK} \mathrm{ha}^{-1}+@ 100 \%\right.$ sulphur ha- $\left.{ }^{-1}\right]$ that showed the highest yield regarding all parameters it, gave the best results with respect to plant height $105.10 \mathrm{~cm}$, number of leaves per plant 22.16, number of branch per plant 11.96, fresh weight $64.73 \mathrm{~g}$ and dry weight $18.50 \mathrm{~g}$, it gave highest yield, $22.04 \mathrm{q} \mathrm{ha}^{-1}$, test weight $3.96 \mathrm{~g}$. Combined use of NPK and sulphur resulted in significant increase on enrichment of soil fertility status. NPK in combination with sulphur resulted in a slight decrease in $\mathrm{pH} 7.50, \mathrm{EC} 0.24 \mathrm{dSm}^{-1}$. Combination of NPK observations resulted in significant increase in OC 0.73 per cent, particle density $2.50 \mathrm{~g} \mathrm{~cm}^{-3}$, bulk density $1.22 \mathrm{~g} \mathrm{~cm}^{-3}$, pore space 50.26 per cent and available $\mathrm{N} 310.16 \mathrm{~kg} \mathrm{ha}^{-1}, \mathrm{P} 27.40 \mathrm{~kg} \mathrm{ha}$ ${ }^{1}, \mathrm{~K} 206.52 \mathrm{~kg} \mathrm{ha}^{-1}$, S 13.24ppm, in the soil. From the economical point of view, the same treatment $\mathrm{T}_{8}$ combination gave the maximum net profit of Rs. (48428.6 ha- $\left.{ }^{-1}\right)$ with C: B ratio of $1: 2.82)$.

Key words : Mustard, yield, Nitrogen, Phosphorus, Potessium, Sulphur

How to cite this article : Nagar, Kailash Chand, Meena, Hemraj and Swaroop, Narendra (2015). Effect of different levels of inorganic fertilizer and sulphur on physico-chemical properties of soil, and yield of mustard (Brassica juncea L.). Asian J. Soil Sci., 10(2) : 222-227. 